\title{
Determining The Optimal Mix of Institutional Geopolitical Power And ASEAN Corporate Governance on the Firm Value of Malaysia's Multinational Corporations (MNCs)
}

\author{
Yusoff Wan Sallha ${ }^{1, *}$, Handayani Wuri ${ }^{1}$, Saad Mohd. Sazli ${ }^{2}$ and Md. Salleh Mohd. Fairuz ${ }^{3}$ \\ ${ }^{1}$ School of Business Innovation and Technopreneurship, Universiti Malaysia Perlis, 01000 Kangar, Perlis, Malaysia. \\ ${ }^{2}$ School of Manufacturing Engineering,Universiti Malaysia Perlis, Ulu Pauh Main Campus, 02600 Arau, Perlis. \\ ${ }^{3}$ School of Accounting, Faculty of Economics and Management, Universiti Kebangsaan Malaysia, 43600 Bangi, Selangor, Malaysia.
}

\begin{abstract}
The purpose of this paper is to examine the relationship between institutional geopolitics, ASEAN corporate governance quality and the firm value of Malaysia's multinational corporation (MNC). We used the data of MNCs in Malaysia that were active from 2009 to 2013 as an evidence of MNCs from emerging market economies. Descriptive analysis, factor analysis and panel data analysis have been utilized to test the equation model. We also propose optimization analysis by using differential evolution method to capture the optimal mix of institutional geopolitics and ASEAN_CG on the firm value of MNC. Results reveal that the geopolitics of G7(Canada, France, German, Italy, Japan, Europe, and the United States), BRICS (Brazil, Russia, India, China, and South Africa), and ASEAN (Brunei Darussalam, Cambodia, Indonesia, Lao PDR, Myanmar, Philippines, Singapore, Thailand, Vietnam, and Malaysia) are highly correlated with the firm value of Malaysia's MNC. The power of institutional geopolitics, namely, military, material, and social power, influences firm value negatively and ASEAN_CG moderate the negative influence of institutional geopolitics on the firm value of MNC. Thus, it is importance for corporate management to understand the geopolitical changes of host countries' and increase the compliance of ASEAN_CG in formulating their market value and segmentation strategies.
\end{abstract}

\section{Introduction}

ASEAN Investment Report (AIR) 2015 highlighted that multinational companies (MNCs) remained a key aspect of the ASEAN investment landscape in 2014 and 2015. Foreign and ASEAN MNCs continue to expand their activities in the ASEAN region in a range of industries. The strong regional expansion by MNCs also played an important role in pushing foreign direct investment (FDI) to a higher level in 2014. In addition, some ASEAN MNCs such as Malaysia's MNC are not just expanding in the same host country but also in other ASEAN states members.

Despite a growing number of ASEAN MNCs investing abroad, very little empirical research has looked deeply into the dynamic aspects of the internationalisation and emergence of Malaysia-based MNCs [1]. In fact, little is known about the systemic risk like geopolitical risk and global governance on the value of MNCs originating in Malaysia. Notwithstanding there is a few recent undertaken studies on the international geopolitical risk in financial literature (e.g.[2],[3]) but their focus mainly on countries financial performance. However, lesson from British exit European Union (Bexit) in the age of non polar world has also forced business strategists to make geopolitical uncertainty a component in corporate decision making. Understanding the geopolitical risk and good governance can help MNCs to avoid costly investment mistakes and allow them to take advantage of opportunities that they might not otherwise [4].

In addition, Malaysia's MNCs play an important role to gear up Southeast Asia Nations (ASEAN) as a single market and production base [5]. The relative benefits and costs of systemic risk in the emerging markets may not necessarily at the same magnitude with the developed countries, which could offer a new way of measuring firm value. This study attempts to fill that gap. The study aims to; first, empirically examine the value impact of institutional geopolitics and global governance on the firm value of MNCs originating from Malaysia. Second, formulate the optimal mathematical model of firm value for Malaysia-base MNCs. The study will be using a quantitative method for the first phase and metaheuristic optimisation method for the second phase. The result of the study will among others, underline policies and recommendations to decision maker to manage risk and resources effectively.

\footnotetext{
Corresponding author: wansallha@unimap.edu.my
} 


\section{Institutional geopolitics, ASEAN corporate governance and firm value}

Institutional geopolitics is the term most used by scholars to explain the major power of multilateral institutions (e.g., G7 countries, BRICS (Brazil, Russia, India, China and South Africa) and South East Asian Corporation (ASEAN)) in influencing world political economy [6]. Despite the hard power strategies such as military intervention, economic sanctions and coercive diplomacy; multilateral institutions may use the soft power approach to persuade others to do what they do not want to do [7]; [8];[6]. The soft power strategies are usually associated with ideology, cultural attraction, natural resources and bilateral relations. Both strategies are considered as an important geopolitical mechanism to corporate strategies because the changes of political decision among institutions member's may affect the activities of foreign companies and diminish the investment process.

The case of Brexit for example, provides a powerful motivation to Malaysia-base MNCs on how geopolitical risk affects firm valuation. After the announcement of Brexit most of the MNCs operating in UK and the rest of Europe experience a job cut and profit discrepancies [9]. MNCs need to have at least a basic plan to secure their value chain [4].

As suggested in network governance theory, the interdependent relationship between public, semi-public and private actors such as G7 countries, BRICS, ASEAN and Malaysia-based MNC, that involve in selforganizing negotiation systems need to have a good governance practices to optimize both; private and common goal [10]. Since Malaysia public listed companies (including MNC companies) fully implemented ASEAN Corporate Governance standard and practices (ASEAN CG) as a new standard that comply with regional and international standard, there is possible that ASEAN_CG able to play as a moderating role to control the geopolitical power of multilateral institution and the value of Malaysia-based MNC. If there is a significant relationship, what are the optimum score of ASEAN_CG that Malaysia's MNC need to comply to maximize the firm value?

To achieve these questions, the quantitative and metaheuristic optimisation methodology will be followed, and hopefully our conclusions may contribute to the construction of ASEAN field of study.

\section{Methodological considerations}

\subsection{Sample selection}

The sample of the study consists of MNC companies listed in Bursa Malaysia that are active from 2009 to 2013. The sampling procedure is identified based on the definition of MNC. Based on previous literature, the classification of the MNC companies is as follows:
Table 1. Classification of MNC companies.

\begin{tabular}{|l|l|l|}
\hline No & Classification procedure & Literature Review \\
\hline 1 & $\begin{array}{l}\text { International segmentation: } \\
\text { Companies that operate in at } \\
\text { least two countries }\end{array}$ & {$[11],[12]$} \\
\hline 2 & $\begin{array}{l}\text { Control of assets /sales } \\
\text { activities: }\end{array}$ & $\begin{array}{l}\text { At least } 10 \text { percent of holding } \\
\text { assets /sales come from its } \\
\text { international subsidiaires }\end{array}$ \\
\hline 3 & $\begin{array}{l}\text { Control of equity: } \\
\text { Holding company holds at } \\
\text { least 20\% equity in its } \\
\text { international subsidiaries }\end{array}$ & {$[11,15]$} \\
\hline
\end{tabular}

We excluded companies from the financial and banking sectors because these companies are subject to different regulations. We also excluded MNC companies that are not fairly distributed across industries such as from the hotel, mining, and IPC industries. The procedure generated 176 companies with total pooled observations of 880 company years.

\subsection{Measures of Firm value}

This study used excess value as proxy for firm value. The excess value is calculated as follows:

Excess Value $(E V)=\frac{\ln (\text { the actual capital to sales ratio) }}{\ln (\text { the imputed capital to sales ratio) }}$

Due to data availability, we employ capital-sales ratio to calculate the actual value of each firm. The formula for capital-sales ratio is as follows :

The actual capital to sale $=\frac{\text { MVE }+ \text { PS }+ \text { DEBT }}{\text { holdings total sales }}$

Where;

MVE : The market value of equity computed as price per share multiplied by the number of outstanding common shares.

PS : $\quad$ The liquidating value of preferred stock.

DEBT : The value of short-term liabilities net of shortterm assets plus the book value of long-term debt.

TA : $\quad$ The book value of total assets.

Next, the imputed value is calculated as the median capital-sales ratio. The median value is obtained from the weighted average of all imputed values computed for each of the firm's segments that operate in the same industry(s). To calculate the imputed value, we group the firm's international segmentation based on G7, BRICS, and ASEAN countries to represent the multilateral geopolitical influence on the firm's international segmentation. Hence, for example, if an plantation MNC has $20 \%$ of its sales in the UK, $20 \%$ in Canada, $30 \%$ in India and $30 \%$ in China, then the imputed value is calculated as follows : 
Imputed value $=(0.4)$ (the value of the median pure-play G7 plantation MNCs) + (0.6) (the value of the median pure-play BRICS plantation MNCs).

We assume that the MNC has the same product mix throughout its various international segments because we do not have the breakdown among product market segments and international regions.

\subsection{Measures of institutional geopolitical influences}

This study used the smart power of G7, BRICS and ASEAN as a proxy to measure the institutional geopolitical influence [16-19]. By using principle component analysis, we measure the smart power of G7, BRICS and ASEAN as follows:

(1) Military power (mp):

1. [ME] Military expenditure (\% of GDP)

2. $[\mathrm{AF}]-\ln [$ Armed forces personnel, total]

(2) Material power (mr):

1. $[\mathrm{OIL}]-\ln$ [Oil: total proved reserves (thousand million barrels)]

2. $[\mathrm{GAS}]-\ln [$ Natural gas: total proved reserves (trillion cubic metres)]

3. $[\mathrm{NCLR}]-\ln [$ Nuclear energy: operable reactors (Mwe)]

4. $[\mathrm{P}]-\ln [$ Population density (people per sq. km of land area)]

5. [S\&T] - Science and technology capability: research and development expenditure (\% of GDP)

(3) Social power (sp):

1. [PV_HS] - $\ln [$ A personal visit/conference/seminar attended by the heads of state of G7, BRICS, or ASEAN countries to Malaysia**.]

2. [PV_M'PM] - $\ln [$ A personal visit/conference/ seminar attended by the prime minister of Malaysia to G7, BRICS, or ASEAN countries**.]

**The score one (1) is given if the above items match and zero (0) for otherwise.

The source of data is taken from The World Bank: World Development Indicator Database, Oil \& Gas Journal, BP Journal, Nuclear Energetic Agency and multimedia photo gallery, Prime Minister's Office, Putrajaya Malaysia.

To analyze the influence of institutional geopolitical on the firm value of MNCs, we multiply the above geopolitical scores with firm's segmentation sales. We assume that holding firms that have their segmentation on G7, BRICS, or ASEAN countries will obtain a stronger geopolitical effect compared with firms that have no segmentation on G7, BRICS, or ASEAN countries.

\subsection{Measures of ASEAN_CG Score}

This study used ASEAN_CG scoring index to measure the moderating effects of ASEAN_CG on the relationship between institutional geopolitics and firm value. We followed ASEAN Corporate Governance Scorecard prepared by [20] as a basic measurement to measure the ASEAN_CG score. However some exemption has been made due to the mandatory disclosure and the availability of data. Mandatory disclosure is excluded because we assume that all firm have comply the requirement.

\subsection{Control Variables}

Based on several variables that have been widely used by earlier studies ([21-23]), this study used control variables as follows:

$$
f(\text { Control })=\beta 0+\beta 1 \mathrm{TOA}+\beta 2 \mathrm{ROA}+\beta 3 \mathrm{LOA}+\varepsilon
$$

Where:

Firm size $(\mathrm{TOA})=$ logarithm of total assets

Profitability $(\mathrm{ROA})=\mathrm{EBIT} /$ total assets

Leverage $(\mathrm{LOA})=$ total debt/total assets

\subsection{Data Analysis}

Descriptive and panel data regression were performed on the gathered data. The equation for the panel data regression is as follows:

$\mathrm{EV}_{\mathrm{i}, \mathrm{t}}=\beta_{0}+\beta_{1} \mathrm{mpG}_{\mathrm{i}, \mathrm{t}}+\beta_{2}$ MRBRICS $_{\mathrm{i}, \mathrm{t}}+\beta_{3}$ SPASEAN $_{\mathrm{i}, \mathrm{t}}$ $+\beta_{4} \mathrm{kmG}_{\mathrm{i}, \mathrm{t}}+\beta_{5}$ mrBRICS $_{\mathrm{i}, \mathrm{t}}+\beta_{6}$ mrASEAN $_{\mathrm{i}, \mathrm{t}}+\beta_{7} \mathrm{spG}_{\mathrm{i}, \mathrm{t}}$ $+\beta_{8} \operatorname{spBRICS}_{\mathrm{i}, \mathrm{t}}+\beta_{9}$ spASEAN $_{\mathrm{i}, \mathrm{t}}+\beta_{10} \mathrm{CGQ}_{\mathrm{i}, \mathrm{t}}+$ $\beta_{11} \mathrm{mpG}_{\mathrm{i}, \mathrm{t}}{ }^{*} \mathrm{CGQ}_{\mathrm{i}, \mathrm{t}}+\beta_{12} \mathrm{mpBRICS}_{\mathrm{i}, \mathrm{t}} * \mathrm{CGQ}_{\mathrm{i}, \mathrm{t}}+$ $\beta_{13} \operatorname{mpASEAN}{ }_{\mathrm{i}, \mathrm{t}} * \mathrm{CGQ}_{\mathrm{i}, \mathrm{t}}+\beta_{14} \mathrm{mrG}_{\mathrm{i}, \mathrm{t}} * \mathrm{CGQ}_{\mathrm{i}, \mathrm{t}}+$ $\beta_{15}$ mrBRICS $_{\mathrm{i}, \mathrm{t}} * \mathrm{CGQ}_{\mathrm{i}, \mathrm{t}}+\beta_{16} \mathrm{mrASEAN}_{\mathrm{i}, \mathrm{t}} * \mathrm{CGQ}_{\mathrm{i}, \mathrm{t}}+$ $\beta_{17} \operatorname{spG}_{\mathrm{i}, \mathrm{t}} * \mathrm{CGQ} \mathrm{i}_{\mathrm{i}, \mathrm{t}}+\beta_{18} \mathrm{spBRICS}_{\mathrm{i}, \mathrm{t}} * \mathrm{CGQ}_{\mathrm{i}, \mathrm{t}}+$ $\beta_{19} \operatorname{SpASEAN}_{\mathrm{i}, \mathrm{t}} * \mathrm{CGQ}_{\mathrm{i}, \mathrm{t}}+\boldsymbol{f}(\mathrm{Control})_{\mathrm{i}, \mathrm{t}+\mathrm{wt}+\mathrm{ni}+\varepsilon \mathrm{it}}$

Where;

$\mathrm{EV}_{\text {it }} \quad=$ firm value

$\mathrm{mp}_{\mathrm{it}} \quad=$ military power

$\mathrm{mr}_{\mathrm{it}} \quad=$ material resources

$\mathrm{sp}_{\mathrm{it}} \quad=$ social power

G7 = G7 countries - [Canada, France, German, Italy, Japan, Europe and the United States]

BRICS = BRICS countries - [Brazil, Russia, India, China, and South Africa]

ASEAN = ASEAN countries - [Brunei Darussalam, Cambodia, Indonesia, Lao PDR, Myanmar, Philippines, Singapore, Thailand, Vietnam, and Malaysia]

CGQ = Corporate governance quality

$f($ Control $)=$ Control variables

$\varepsilon_{\text {it }} \quad=$ error term

The i subscript denotes the cross-section dimension, and $\mathrm{t}$ denotes the time-series dimension. 


\subsection{Measures of firm value optimization}

By using the EV equation results, this study proceeds with firm value optimization. To measure firm value optimization, we employed one of the evolutionary algorithms (EA) methods, which is differential evolution (DE) by using MatLab Versi 8. The benefit of using EA method is that first, EA search a population of points in parallel, not just a single point. Second, EA do not require derivative information or other auxiliary knowledge; only the objective function and corresponding fitness levels influence the directions of search and third EA are generally more straightforward to apply, because no restrictions for the definition of the objective function exist [24].

Generally, some DE operator must be considered by $\mathrm{DE}$ algorithm as shown in Table 2 below:

Table 2. Value of DE operator.

\begin{tabular}{lll}
\hline Dimension of problem & $\mathrm{D}$ & 10 \\
Population size & $\mathrm{NP}$ & 100 \\
Differentiation constant & $\mathrm{F}$ & 0.6 \\
Crossover rate & $\mathrm{CR}$ & 0.9 \\
Generations/Stopping condition & $\mathrm{GEN}$ & 500 \\
\hline
\end{tabular}

\section{Results}

\subsection{Descriptive analysis}

Table 3 shows that the majority of MNC segmentation was from ASEAN countries (69.92\%), followed by BRICS $(52.10 \%)$ and G7 $(42.57 \%)$ countries. Industrial product shows the highest percentage with $41.54 \%$, and plantation industries obtained the lowest percentage of industry involvement with $3.97 \%$.

Table 3. Descriptive analysis.

\begin{tabular}{lcc}
\hline & \multicolumn{2}{c}{ Total years of observation } \\
\cline { 2 - 3 } Sample/variables & frequency & percentage \\
\hline Total segmentation of G7 & 375 & 42.57 \\
Total segmentation of BRICS & 459 & 52.10 \\
Total segmentation of ASEAN & 616 & 69.92 \\
$\quad$ Total sample by industry: & & \\
1. Construction & 45 & 5.11 \\
2. Consumer & 195 & 22.13 \\
3. Industrial product & 366 & 41.54 \\
4. Plantation & 35 & 3.97 \\
5. Technology & 60 & 6.81 \\
6. Trading and services & 180 & 20.43 \\
\hline Total & 881 & 100 \\
\hline
\end{tabular}

\subsection{Regression analysis}

Based on panel data analysis procedure, we begins regression analysis with comparing the pooled OLS regression and fixed effects model. The result of the fixed effects model shows that all $\alpha \mathrm{i}$ are zero, which means that the OLS estimator is biased and inconsistent. Thus, the null hypothesis is rejected.
We also compared the random effects and fixed effects models to determine the best statistical estimation and conducted the Hausman test to verify the presence of correlations between the unobservable heterogeneity and explanatory variables. Again, the probability is less than 0.05 . Thus, we reject the null hypothesis and continued with the fixed effects regression model. To ensure the validity of the statistical results, we conducted a modified Wald test and serial correlation test. Both statistical tests show a heteroskedasticity and serial correlation problem in the fixed effects (FE) model.

Thus, to rectify these problems, we performed the fixed effects (within) regression with Driscoll and Kraay standard errors by using the xtscc command implemented by Daniel Hoechle. The error structure is assumed to be heteroskedastic and autocorrelated up to some lag, and possibly correlated between groups. Figure 4 shows the results of fixed effects (within) regression with Driscoll and Kraay standard errors.

Table 4. The relationship of institutional geopolitics, ASEAN corporate governance and firm value.

\begin{tabular}{|c|c|c|c|c|}
\hline Variables & Model & (a) & Model & \\
\hline Pemalar & -0.149 & & -0.211 & \\
\hline mpG7 & -0.212 & $* * *$ & -0.308 & \\
\hline mrG7 & -0.125 & $* *$ & 0.067 & \\
\hline spG7 & -0.013 & & -0.135 & * \\
\hline mpBRICS & 0.015 & & 0.960 & $* *$ \\
\hline mrBRICS & -0.124 & $* * *$ & -0.563 & $* *$ \\
\hline spBRICS & -0.103 & $* * *$ & 0.143 & \\
\hline mpASEAN & -0.073 & $* *$ & 0.368 & $* *$ \\
\hline mrASEAN & -0.124 & $* *$ & -0.342 & \\
\hline spASEAN & -0.076 & $* *$ & -0.022 & \\
\hline CGQ & & & 0.521 & $*$ \\
\hline $\mathrm{mpG} 7 * \mathrm{CGQ}$ & & & 0.173 & \\
\hline $\mathrm{mrG7} 7 \mathrm{CGQ}$ & & & 0.362 & \\
\hline $\mathrm{spG} 7 * \mathrm{CGQ}$ & & & 0.211 & \\
\hline mpBRICS*CGQ & & & 1.536 & $* *$ \\
\hline mrBRICS*CGQ & & & 0.690 & $*$ \\
\hline spBRICS*CGQ & & & 0.409 & \\
\hline mpASEAN*CGQ & & & 0.776 & $* * *$ \\
\hline mrASEAN*CGQ & & & 0.370 & \\
\hline spASEAN*CGQ & & & -0.101 & \\
\hline TOA & -0.362 & * & -0.375 & * \\
\hline ROA & 0.130 & & 0.089 & \\
\hline LOA & 0.253 & $*$ & 0.234 & $*$ \\
\hline Prob $>F$ & 0.0001 & $* * *$ & 0.0004 & $* * *$ \\
\hline R-squared & $36.34 \%$ & & $40.02 \%$ & \\
\hline Max lag / (N) & $2 /(880)$ & & $2 /(880)$ & \\
\hline
\end{tabular}

Model (a) presents the direct effects of institutional geopolitics on firm value. The result supports the idea that the powers of institutional geopolitics are negatively correlated with an MNC's firm value. Specifically, all geopolitical factors, except for military power of BRICS and social power of G7, are statistically significant to firm value. These results also suggest that the military and material power of $\mathrm{G} 7$ countries and social power of BRICS are the most important determinant in international location choices for MNCs in Malaysia, with the highest coefficient values of $-0.212,-0.125$, and -0.103 respectively. 
Next, model (b) presents the interaction effects of corporate governance quality on the relationship of institutional geopolitics and firm value. Comparing the results between modal (a) and model (b); the $\mathrm{R}^{2}$ score increase by $3.68 \%$. This shows that there is an interaction between corporate governance quality and the relationship of institutional geopolitics and firm value. Specifically, the quality of ASEAN_CG weaken the relationship between military power of BRICS, material power of BRICS and social power of ASEAN on the firm value of Malaysia's MNC. Thus on the basis of these results, we derive an econometric model of the institutional geopolitics, corporate governance and firm value as follows:

$\mathrm{EV}=0.960 * \mathrm{mpBRICS}+0.368 * \mathrm{mpASEAN}-0.563 * \mathrm{mrBRICS}$ $-0.135 *$ spG7 + $0.521 *$ CGQ + 1.536*mpBRICS_CGQ + $0.776^{*} \mathrm{mpASEAN} \_\mathrm{CGQ}+\quad 0.690^{*} \mathrm{mrBRICS} \_\mathrm{CGQ}-$ $0.375 * \mathrm{TOA}+0.234 * \mathrm{LOA}$

\section{3 firm value optimization}

Based on equation 5, we derived firm value optimization. The results in Figure 1 (a) and (b) show that the maximum firm value of Malaysia's MNC can be achieved at 9.2512 .

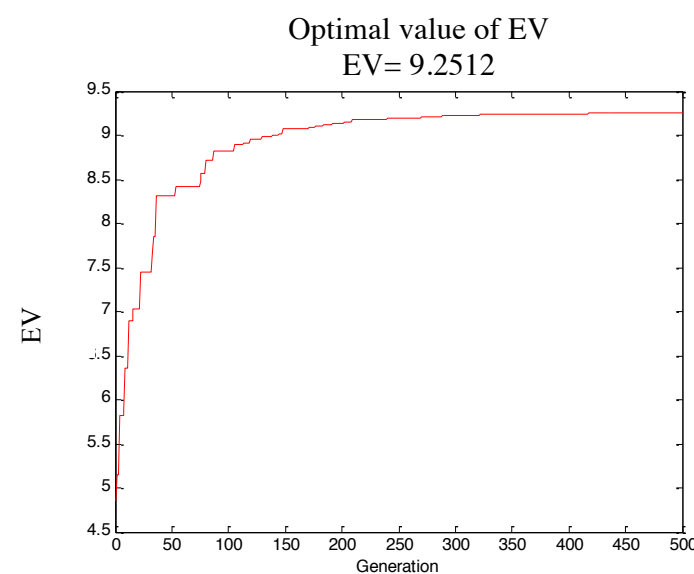

Figure 1 (a). Convergence profile - EV

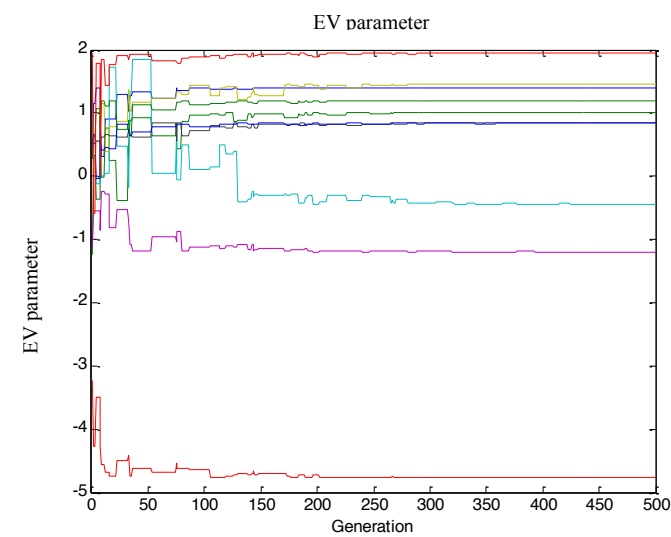

Figure 1 (b). Convergence profile- X parameter

Specifically, we compare the mean results of independent variables between optimization value and regression value. Based on result in table 5; it shows that to maximize firm value to 9.2512 Malaysia's MNC need to comply at least $84.1 \%$ of corporate governance score. The current score is $59.5 \%$. Thus MNC company need to increase their corporate governance quality at least $24.6 \%$ from the current score.

Table 5. The differences between independent variables optimization mean and regression mean.

\begin{tabular}{llrrr}
\hline No & \multicolumn{1}{c}{$\begin{array}{c}\text { Independent } \\
\text { variables }\end{array}$} & $\begin{array}{c}\text { Optimum } \\
\text { mean }\end{array}$ & $\begin{array}{c}\text { Regression } \\
\text { mean }\end{array}$ & Differences \\
\hline 1 & mpBRICS & 1.404 & $1.07 \mathrm{E}-08$ & 1.404 \\
2 & mpASEAN & 1.016 & $1.15 \mathrm{E}-08$ & 1.016 \\
3 & mrBRICS & -4.77 & $-1.04 \mathrm{E}-08$ & -4.770 \\
4 & spG7 & -0.444 & $-4.42 \mathrm{E}-09$ & -0.444 \\
5 & TOA & -1.198 & 0.040 & -1.238 \\
6 & LOA & 1.459 & 0.371 & 1.088 \\
7 & CGQ & 0.841 & 0.595 & 0.246 \\
8 & mpBRICSCGQ & 0.003 & 0.003 & 0.000 \\
9 & mpASEANCGQ & 1.196 & -0.008 & 1.204 \\
10 & mrBRICSCGQ & 1.945 & -0.011 & 1.956 \\
\hline
\end{tabular}

\section{Discussions and Conclusion}

In this study, we developed a new conceptual framework to explain how and why institutional geopolitics can be present and have some influence on the firm value of Malaysia MNCs. By introducing a new concept and methodology that are yet unused in the literature, we intend to obtain several evidences. First, institutional geopolitics play an important role in fitting international segmentation decisions. Second, ASEAN_CG is a good moderating function to weaken the negative relationship between institutional geopolitics and the firm value of Malaysia's MNC and third, to maximize the firm value of Malaysia's MNC the top management should comply at least $84.1 \%$ of ASEAN-CG score.

This study also contributes to the results of Minority Shareholder Watchdog Group [25] by providing a new evidence that MNCs from emerging market economies are also exposed to international geopolitical challenge. In addition, we complement the report of ASEAN Capital Market Forum (ACMF) [20] by proving that ASEAN_CG able to promote ASEAN as an asset class. This is an important issue for future research.

\section{Reference}

1. Ahmad, S.Z., The internationalization process of third world multinational firms: A study of Malaysia government linked corporation. International Journal of Business Research, 2008. 8(5): p. 35-47.

2. Salehi, H., et al., Foreign-Currency and Monetary Geopolitics of United States and Its Effects on the Future of the International System. Journal of Economics and Sustainable Development, 2014. 5(8): p. 96-104.

3. Kapur, D. and M. Suri, Geoeconomics Versus Geopolitics: Implications for Asia. The Oxford Handbook of the Economics of the Pacific Rim, 2013: p. 290.

4. Frontier Strategy Group, Business After Brexit: What MNCs Need to Know, in Frontier Strategy Group. 2016, WordPress. 
5. BERNAMA, Malaysia And ASEAN Gear Up For $A E C$, in Malaysian Digest 2015.

6. Yusoff, W., et al., The Geopolitics of ASEAN Cooperation and Firm Value: Evidence from Multinational Corporation in Malaysia. Journal of Global Business and Social Entreprenuership (GBSE) 1 (2), 2016.

7. Nye, J.S., Soft power. Foreign policy, 1990: p. 153171.

8. Virmani, A., World Economy, Geopolitics and Global Strategy: Indo-US Relations in the 21st Century. Economic and Political Weekly, 2006: p. 4601-4612.

9. Fels, J., What is Brexit's Impact on Global Economy? A Pimco analyst assesses the economic fallout over the coming three to five years., in Wall Street's Best Minds, Barron's Asia. 2016.

10. Jones, C., W.S. Hesterly, and S.P. Borgatti, A General Theory of Network Governance: Exchange Conditions and Social Mechanisms. The Academy of Management Review, 1997. 22(4): p. 911-945.

11. Ramasamy, B., Third world multinationals: The case of Malaysia. Analisis, 1999. 6(1\&2): p. 123137.

12. Martinez, Z.L. and D.A. Ricks, Multinational parent companies' influence over human resource decisions of affiliates: US firms in Mexico. Journal of International Business Studies, 1989: p. 465-487.

13. Hashim, F. and N. Mohd Saleh, Voluntary annual report disclosures by Malaysian multinational corporations. 2007.

14. Michel, A. and I. Shaked, Multinational corporations vs. domestic corporations: Financial performance and characteristics. Journal of International Business Studies, 1986: p. 89-100.

15. Mustapha, M., Monitoring Costs of Multinational Companies: An Agency Theory Perspective. Asian Journal of Business and Accounting, 2014. 7(2): p. 23.

16. Reynaud, J. and J. Vauday, Geopolitics and international organizations: An empirical study on IMF facilities. Journal of Development Economics, 2009. 89(1): p. 139-162.

17. Armijo, L.E., L. Mühlich, and D.C. Tirone, The systemic financial importance of emerging powers. Journal of Policy Modeling, 2014. 36, Supplement 1(0): p. S67-S88.

18. Teixeira, A.A.C. and M. Dias, The importance of geopolitics in firms' international location decisions: The Polish case. Communist and PostCommunist Studies, 2013. 46(1): p. 79-93.

19. Md Salleh, M.F., Y. Wan Sallha, and N. Basnan, Does Smart Power of ASEAN Cooperation Influence Firm Value? Evidence from Geopolitical Perspective. Acta Universitatis Danubius. Economica, 2016. 12(3).

20. ACMF, ASEAN corporate governance scorecard: Country reports and assessments 2012-2013. 2013, Asian Development Bank.

21. Ang, J.S., D.K. Ding, and T.Y. Thong, Political Connection and Firm Value. Asian Development Review, 2013. 30(2): p. 131-166.
22. Berger, P.G. and E. Ofek, Diversification's effect on firm value. Journal of Financial Economics, 1995. 37(1): p. 39-65.

23. Brick, I.E. and N.K. Chidambaran, Board meetings, committee structure, and firm value. Journal of Corporate Finance, 2010. 16(4): p. 533-553.

24. Saad, M.S., H. Jamaluddin, and I.Z.M. Darus, Active Vibration Control of Flexible Beam using Differential Evolution Optimisation. World Academy of Science, Engineering and Technology, International Journal of Mechanical, Aerospace, Industrial, Mechatronic and Manufacturing Engineering, 2012. 6(2): p. 446-453.

25. MWSG, MALAYSIA-ASEAN Corporate Governance Report 2012. 2013, Minority Shareholder Watchdog Group. 